\title{
Effect of Molecular Weight Reduction of Polypeptides on Angiotensin Converting Enzyme (ACE) Inhibitory Activity in Chicken Skin Hydrolysate (Collagen)
}

\author{
Salma Gulam Husain, Nur Aliah Daud and Abdul Salam Babji \\ School of Chemical Science and Food Technology, Faculty of Science and Technology, Universiti
Kebangsaan Malaysia
}

\begin{abstract}
Inhibition of Angiotensin Converting Enzyme (ACE) reduces blood pressure and gives an anti-hypertensive effect. Chicken skin is an undesirable by-product of the poultry industry, disliked by consumer because of the high fat content. The aim of this research is to determine the effect of molecular weight reduction on ACE inhibition activity in chicken skin hydrolysate. Chicken skin is prepared by manually defatting, soaked in acetone and in $0.1 \mathrm{M}$ phosphate buffer. Sample hydrolysis is carried out using alcalase enzyme for a duration of 4 hours at $60^{\circ} \mathrm{C}$ and $\mathrm{pH} 9.5$. The best degree of hydrolysis $(\mathrm{DH})$, at 4th hour, with value of $49.54 \pm 0.79 \%$, is ultrafiltrated and used in ACE inhibition activity detection. The sample weight $\geq 10 \mathrm{kDa}, 3-10 \mathrm{kDa}$ and $\leq 3 \mathrm{kDa}$ contains $5.63 \pm 0.01 \mathrm{~g} / \mathrm{L}, 2.84 \pm 0.06 \mathrm{~g} / \mathrm{L}$ and $1.07 \pm$ $0.18 \mathrm{~g} / \mathrm{L}$ peptide content respectively whereas soluble protein content is $0.51 \mathrm{mg} / \mathrm{mL}$ for sample weight $\geq 10 \mathrm{kDa}, 0.27$ $\mathrm{mg} / \mathrm{mL}$ for sample weight $3-10 \mathrm{kDa}$ and $0.23 \mathrm{mg} / \mathrm{mL}$ for sample weight $\leq 3 \mathrm{kDa}$. The ACE inhibition activity in sample weight $\leq 3 \mathrm{kDa}$ is highest with value of $80.38 \pm 2.69 \%$ followed by sample weight $3-10 \mathrm{kDa}$ with a value of $49.40 \pm$ $2.63 \%$ and sample weight $\geq 10 \mathrm{kDa}$ with value of $42.73 \pm 5.08 \%$. Significant differences $(P \leq 0.05)$ exist between sample weight $\leq 3 \mathrm{kDa}$ and $>3 \mathrm{kDa}$. This research shows that molecular weight reduction increases ACE inhibition activity.
\end{abstract}

Keyword: Angiotensin Converting Enzyme (ACE), chicken skin, inhibitory, weight.

\section{INTRODUCTION}

Angiotensin Converting Enzyme (ACE) is an enzyme that effects hypertension or increases blood pressure. ACE is a dipeptidylcarboxypeptidase that converts the inactive decapeptide angiotensin I into the potent and active vasoconstrictor. It also deactivates the bradykinin, which functions as a vasodilating agent [1]. The inhibition on the ACE activity gives antihypertensive affect to individuals. The activity of ACE inhibitor can be observed in food containing protein, through the presence of bioactive peptides. Bioactive peptides are specific and dependent on the arrangement of the peptide chain. Certain peptide presence can inhibit the ACE activity. Although these peptides can be found in meat, the peptide presence is hidden in the core protein network and is only released in the presence of proteolysis enzymes, such as microbial and proteinase digestion [2].

Chicken skin is used as a raw material in this study because it is an unwanted by-product of the poultry industry, disliked by consumer and causes waste disposal problems [3]. Research by Onuh et al. [4] has reported that defatted chicken skin has high protein content which directly increases amino acid content and bioactive peptide availability which will increase the nutritional and functional value of chicken skin. Apart

${ }^{*}$ Address correspondence to this author at the School of Chemical Science and Food Technology, Faculty of Science and Technology, Universiti Kebangsaan Malaysia; Tel: +603-89215988; Fax: +603-89213232;

E-mail: daging@ukm.edu.my from that, research by Abedin and Riemschneider [5] reported that chicken skin contains $75 \%$ type I collagen and $15 \%$ type III collagen, which can release the amino acid proline and hydroxyproline, that plays a role in the ACE inhibitory peptide [6, 7]. This is also supported by Kim [8] that states chicken skin is a source of collagen and can be used as alternative to collagen from bovine and porcine.

The objectives of this study is to determine the ACE inhibition activity in chicken skin hydrolysate and to determine the effect of molecular weight reduction of polypeptides on the ACE inhibition activity in chicken skin hydrolysate.

\section{MATERIALS AND METHODS}

\section{Sample Preparation}

The chicken skin, obtained from Bandar Baru Bangi market was manually defatted to produce $250 \mathrm{~g}$ of raw material. The chicken skin was then defatted according to Onuh et al. [4] with modification. The manually defatted sample was then soaked in acetone with a ratio of $1 \mathrm{~g}$ to $5 \mathrm{ml}$ for 2 hours until fat layer is effectively removed. Acetone was used because it is an organic solvent that can solubilise the fat portion while the protein portion is precipitated. It is also a convenient fat removal technique because it evaporates easily and can be removed from the sample rapidly without affecting the protein fraction of the sample compared to the traditional method of using 
detergent where there is a difficulty in the separation of the solvent from the sample [9]. Sample is dried overnight in the fume hood to evaporate excess acetone. Sample in petri dish is freezed at $-20{ }^{\circ} \mathrm{C}$ for 24 hours and subsequently freeze dried. The freeze dried sample is blended using a Warring blender to produce dried powder before soaking in $0.1 \mathrm{M}$ phosphate buffer, $\mathrm{pH} 6.6$ at a ratio of $1 \mathrm{~g}$ to $40 \mathrm{~mL}$ for 2 hours at $37{ }^{\circ} \mathrm{C}$. The sample is then centrifuged at $10000 \times \mathrm{g}$ for 40 minutes to produced sample palets, that are air dried in fume hood and used in the consequent test.

\section{Hydrolysis}

The pallet was suspended in distilled water with ratio of $1: 100(\mathrm{w} / \mathrm{v})$ and incubated with $1 \%$ alcalase $\left(\mathrm{pH} 9.5 ; 60^{\circ} \mathrm{C}\right)$ for duration of 4 hours. The enzymatic hydrolysis was stopped by boiling for 5 minutes. The hydrolysate was centrifuged at $3000 \mathrm{~g}$ for 20 minutes and the soluble aqueous fraction was decanted and lyophilized.

\section{Degree of Hydrolysis}

The degree of hydrolysis was determined using method modified o-phthaldialdehyde (OPA) spectrophotometric assay [10, 11]. Fifty milliliters of fresh OPA reagent was prepared by mixing $25 \mathrm{ml}$ of $100 \mathrm{mM}$ sodium tetra hydroborate, $2.5 \mathrm{ml}$ of $20 \%(\mathrm{w} / \mathrm{w})$ sodium dodecyl sulphate, $40 \mathrm{mg}$ of OPA solution (dissolved in $1 \mathrm{ml}$ of methanol) and $100 \mathrm{ml}$ of bmercaptoethanol and then adjusted the volume to 50 $\mathrm{ml}$ with deionized water. 50 microlitres of hydrolysate, containing 5-100 lug protein, was mixed with $2 \mathrm{ml}$ of OPA reagent and incubated for $2 \mathrm{~min}$ at room temperature. The absorbance at $340 \mathrm{~nm}$ was measured with a spectrophotometer (Model UV160A). The degree of hydrolysis was calculated as follow:

$\%$ Degree of Hydrolysis $(\mathrm{DH})=\frac{\mathrm{h}}{\mathrm{h}_{\text {total }}} \times 100$

Where $h_{\text {total }}$ is total peptide bind per protein equivalent and $\mathrm{h}$ is number of peptide hydrolysate.

\section{Ultrafiltration}

The hydrolysate solution was filtered by $0.2 \mu \mathrm{m}$ membrane and separated into large and low molecular weight fractions by ultrafiltration at $4^{\circ} \mathrm{C}$ using $10 \mathrm{kDa}$ Molecular weight cut-off (MWCO) membrane (Vivaflow 200) and 3 kDa MWCO (Vivaflow 50) membrane. Both membranes were activated by spinning $100 \mathrm{ml}$ of deionized water prior to use. This permeate was defined as small peptides with molecular weight $\leq$ 3kDa, 3 - $10 \mathrm{kDa}$ and $\geq 10 \mathrm{kDa}$.

\section{Peptide Content}

The peptide contents of hydrolysates were measured by the method of Church et al. [12] with some modifications using o-phthaldialdehyde (OPA) spectrophotometric assay. Fifty milliliters of fresh OPA reagent was prepared by mixing $25 \mathrm{ml}$ of $100 \mathrm{mM}$ sodium tetra hydroborate, $2.5 \mathrm{ml}$ of $20 \%$ (w/w) sodium dodecyl sulphate, $40 \mathrm{mg}$ of OPA solution (dissolved in $1 \mathrm{ml}$ of methanol) and $100 \mathrm{ml}$ of b-mercaptoethanol and then adjusted the volume to $50 \mathrm{ml}$ with deionized water. 50 microlitres of hydrolysate, containing 5-100 $\mu \mathrm{g}$ protein, was mixed with $2 \mathrm{ml}$ of OPA reagent and incubated for $2 \mathrm{~min}$ at room temperature. The absorbance at $340 \mathrm{~nm}$ was measured with a spectrophotometer (Model UV-160A) using Casein tryptone in phosphate buffer $(\mathrm{pH}: 7.4)$ as the standard to quantify the peptide content.

\section{Protein Solubility}

The Folin-Lowry method was used to determine the soluble protein content [13]. An aliquot of $0.5 \mathrm{ml}$ of the sample was mixed with $0.7 \mathrm{ml}$ of an alkaline-copper reagent and incubated for $20 \mathrm{~min}$ at room temperature. The mixture was added to $0.1 \mathrm{ml}$ of the FolinCiocalteu's phenol reagent at 2-fold dilution with deionized water and allowed to stand for $30 \mathrm{~min}$ or longer at room temperature. The absorbance at 750 $\mathrm{nm}$ was measured with a spectrophotometer (Model UV-160A). The soluble protein content was quantified using bovine serum albumin as the standard.

\section{Determination of Ace Inhibitory Activity}

The ACE inhibitory activity was assayed with RPHPLC modified from the spectrophotometric method described by Wu et al. [14]. Commercial ACE (1 unit) was diluted in $50 \mathrm{mM}$ Tris- $\mathrm{HCl}(\mathrm{pH}: 7.5)$ containing 300 $\mathrm{mM} \mathrm{NaCl}$ to obtain concentration of $100 \mathrm{mU} / \mathrm{ml}$. Aliquots of $100 \mu \mathrm{l}$ were then stored at $-20^{\circ} \mathrm{C}$. A volume of $25 \mu \mathrm{l}$ containing $1.0 \mathrm{mg} / \mathrm{mL}$ concentration of different weight hydrolysate was added to $100 \mu \mathrm{l}$ solution containing $5 \mathrm{~mm}$ Hippuryl-L-Histidyl-LLeucine (HHL). Sample hydrolysate and $\mathrm{HHL}$ were prepared in 100 $\mathrm{mM} \mathrm{Na-borate} \mathrm{buffer,} \mathrm{pH}$ 8.3, containing $300 \mathrm{mM}$ $\mathrm{NaCl}$. After incubation at $37^{\circ} \mathrm{C}$ for $10 \mathrm{~min}, 10 \mu \mathrm{l}$ of ACE $(100 \mathrm{mU} / \mathrm{ml})$ was added and samples were incubated 
for $30 \mathrm{~min}$ at $37^{\circ} \mathrm{C}$. The enzyme reaction was stopped by the addition of $100 \mu \mathrm{l}$ of $1 \mathrm{M} \mathrm{HCl}$. The solution was filtered through a $0.45 \mu \mathrm{m}$ nylon syringe filter and injected directly onto a symmetry shield $\mathrm{C} 18$ column to separate the product and hippuric acid (HA) from HHL. The column was eluted with $50 \%$ methanol in water $(\mathrm{v} / \mathrm{v})$ containing $0.1 \%$ TFA at a flow rate of $1 \mathrm{ml} / \mathrm{min}$ and the absorbance was measured at $228 \mathrm{~nm}$. The instrument consisted of a Jasco PU-980 intelligent pump equipped with Waters 2487 dual absorbance detector. The evaluation of ACE inhibition was based on the comparison between the concentration of HA in the presence or not (control sample) of an inhibitor. After injection in HPLC of the control and the assay with inhibitor, the HA peak areas obtained in the two cases were measured.

Percentage of ACE inhibition activity $=\frac{B-A}{B} \times 100$

where $A$ is the relative area of $H A$ peak generated in the presence of ACE inhibitor component and $B$ the relative area of HA peak generated without ACE inhibitors.

\section{Statistical Analysis}

Results were compared using mean \pm standard deviation between samples containing enzyme and samples not containing enzyme. The significance value $(p<0.05)$ between samples was determined using Duncan Multiple Test and the program used is SPSS.

\section{RESULTS AND DISCUSSION}

$2.0 \mathrm{~g}$ of chicken skin was manually defatted before soaking in acetone to remove the fat layer from the skin. The sample is then freeze dried and soaked in 0.1 $\mathrm{M}$ phosphate buffer, at $\mathrm{pH} 6.6$ and temperature $37^{\circ} \mathrm{C}$ to produce $51.17 \mathrm{~g}$ of dried raw chicken skin sample. The dried chicken skin contains $24.55 \%$ protein and $3.25 \%$ fat. The low fat content in sample indicates an efficient fat removal. The low fat content in the sample is also desirable in hydrolysis process to reduce the formation of protein-lipid complex, which affects the formation of a stabil protein hydrolysate, and subsequently affects the angiotensin converting enzyme (ACE) inhibitory activity $[15,16]$.

Based on Table 1, the highest degree of hydrolysis is at the fourth hour with a value of $49.54 \pm 0.78 \%$. The high value at fourth hour indicates who more peptide bonds are broken down by the enzyme in that time duration. A similar result was reported by Zhang et al. [17], where increase in time indicates a higher degree of hydrolysis $(\mathrm{DH})$ value. Although the $\mathrm{DH}$ value does not achieve the desired $80 \%$ to increase the detection of functional properties of bioactive peptides as indicated by Kristinsson \& Rasco [18], study by Zhang et al. [17] reported that $\mathrm{DH}$ value does not affect ACE inhibitory activity, but the ACE inhibitory activity is affected the the ability of the enzyme used in producing specific protein chain containing hydrophobic amino acid at the C- terminal of tripeptides. This is supported by Arihara et al. [19] that reported that ACE inhibitory activity is affected by the enzyme specific activity in producing specific peptide chain.

Table 1: Degree of Hydrolysis (DH) for Chicken Skin Hydrolysed with Alcalase At Different Time

\begin{tabular}{|c|c|}
\hline Time & Degree of Hydrolysis (\%) \\
\hline \hline 1 hour & $21.65 \pm 2.37^{\mathrm{a}}$ \\
\hline 2 hour & $28.11 \pm 2.00^{\mathrm{b}}$ \\
\hline 3 hour & $48.99 \pm 4.26^{\mathrm{c}}$ \\
\hline 4 hour & $49.54 \pm 0.79^{\mathrm{c}}$ \\
\hline
\end{tabular}

${ }^{a-c}$ Same letter at different column indicates no significant difference $(P>0.05)$. *Mean \pm SD for 3 sample/treatment.

Peptide content are then analysed using ophthaldialdehyde (OPA) spectrophotometric assay to ensure presence of peptide in samples, which may affect ACE inhibitory activity. Spectrophotometer operates on the basic principle of passing a beam of light, which consist of a stream of photons, through a sample and measuring the intensity of light reaching the detector. The fraction of light from the original beam that passes through the sample and reaches the detector is known as transmitter, whereaas absorbance is the fraction of light that do not reach the detector and is absorbed by the sample. The absorbance value measured by the spectrophotometer is used in the determination of the concentration of a sample because it indicates the amount of photon absorbing molecules in the sample. The peptide content of the sample are summarized in Graph 1, where the highest peptide content is in sample with molecular weight $\geq 10$ $\mathrm{kDa}$ with value of $5.63 \pm 0.01 \mathrm{~g} / \mathrm{L}$ and sample with molecular weight $\leq 3 \mathrm{kDa}$ has peptide content of $1.07 \pm$ $0.18 \mathrm{~g} / \mathrm{L}$. The low peptide content present in sample with smaller molecule weight may be attributed to the ultrafiltration process which may have separated the larger weight peptides from the sample causing a low peptide content value. This theory is also supprted by Wu \& Ding and Tsai et al. [14, 20] which states that 


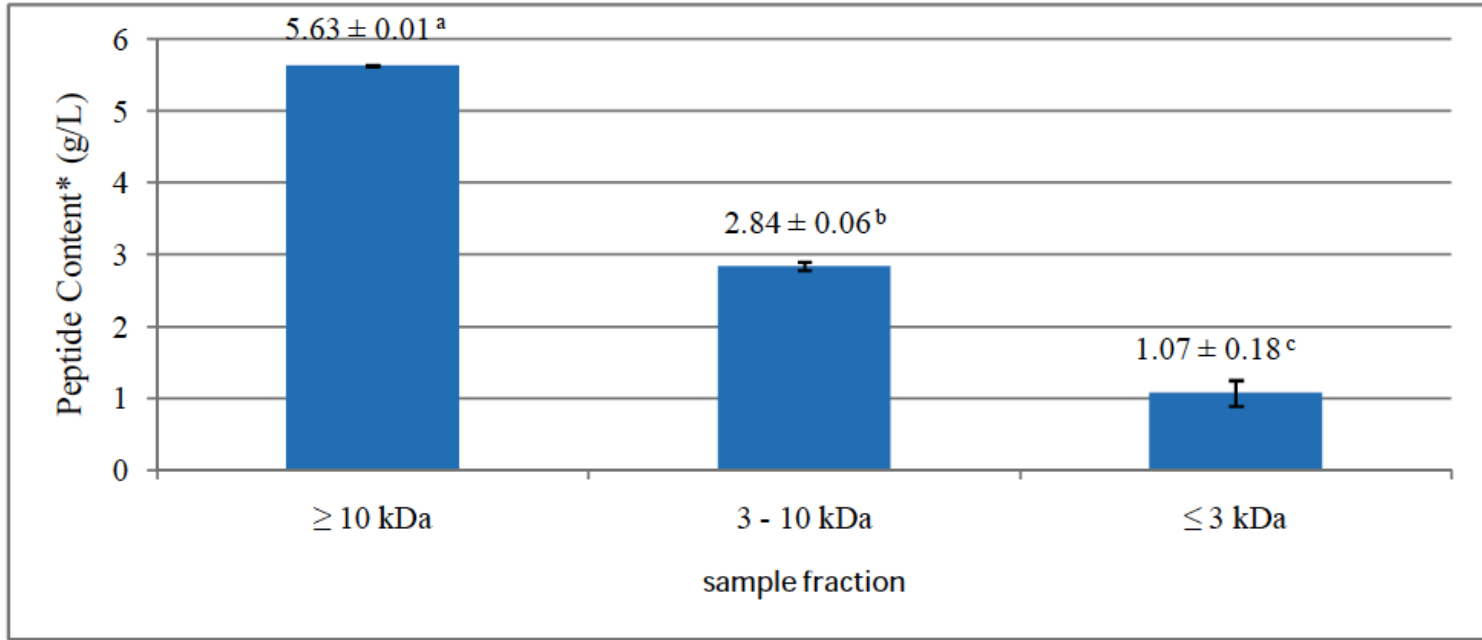

Graph 1: Peptide Content in ultrafiltrated sample fraction of chicken skin hydrolysate*.

${ }^{a-c}$ Same letter at different samples indicates no significant difference $(P>0.05)$.

*Mean \pm SD for 3 sample/treatment.

ultrafiltration process causes a lower peptide content and amino acid content in sample and sample with smaller molecular size, will have a lower peptide content.

The soluble protein content in sample with different molecular weight are then measured using Folin- Lowry method and summarized in Graph 2. The sample with molecular weight $\geq 10 \mathrm{kDa}$ has the highest soluble protein content that is $0.51 \pm 0.10 \mathrm{mg} / \mathrm{mL}$ whereas sample with molecular weight $\leq 3 \mathrm{kDa}$ has the lowest soluble protein content that is $0.23 \pm 0.03 \mathrm{mg} / \mathrm{mL}$. The low soluble protein content obtained from sample with lower molecular weight may be caused by the separation of large molecular weight peptides from sample during the ultrafiltration process. Soluble protein content is analysed in the research to evaluate the content of the tyrosin, cysteine, cystine, histidine dan tryptophan in the samples. These amino acids are able to convert the molybdate in folin-phenol reagent into the blue molybdium [21, 22]. According to [23-26], ACE inhibitory activity is affected by the presence of the amino acid proline, phenylalanine or tyrosin at the terminal-C of peptide chain. Therefore the increase of the soluble protein content, may increase presence of these amino acids which can affect the ACE inhibitory activity.in the ultrafiltrated sample fraction hydrolysates.

Graph 3 summarizes the result obtained for the percentage of ACE inhibitory activity in the ultrafiltrated sample fraction hydrolysates at concentration of 1.0 $\mathrm{mg} / \mathrm{mL}$. The ACE inhibitory activity is calculated by

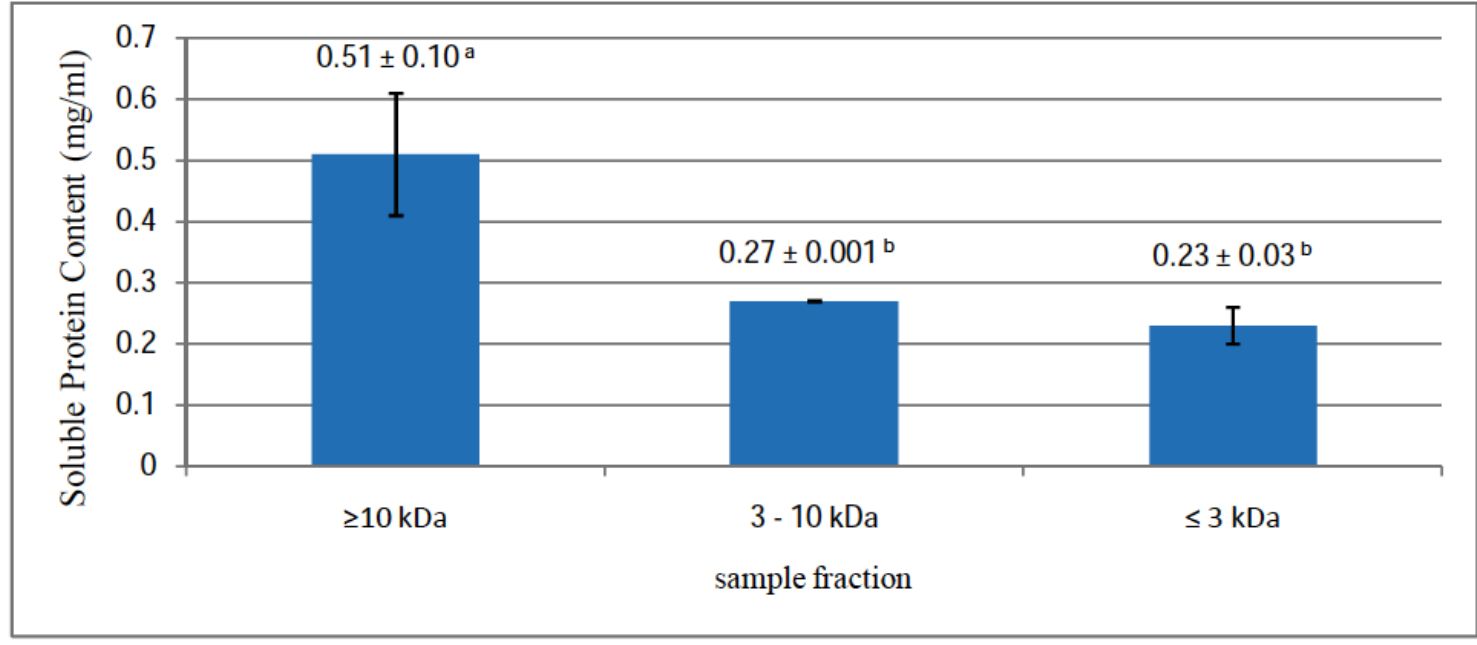

Graph 2: Soluble Protein Content in ultrafiltrated sample fraction of chicken skin hydrolysate*.

${ }^{a-c}$ Same letter at different samples indicates no significant difference $(P>0.05)$.

*Mean \pm SD for 3 sample/treatment. 


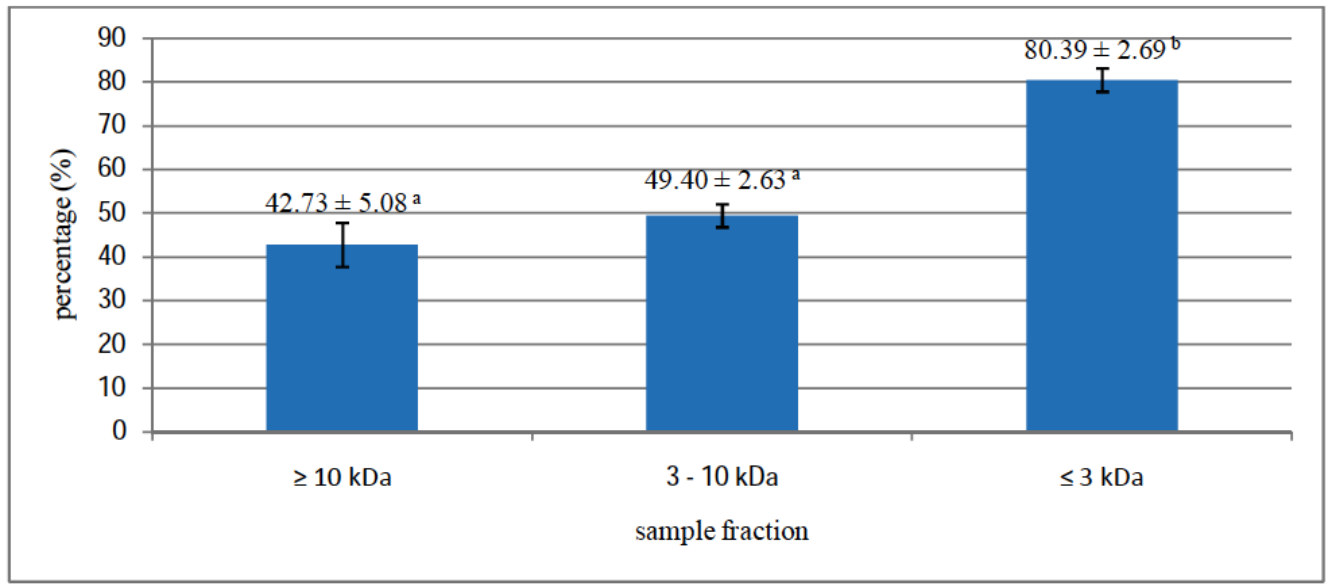

Graph 3: Percentage of angiotensin converting enzyme (ACE) inhibitory activity in ultrafiltrated sample fraction of chicken skin hydrolysate*.

${ }^{a-c}$ Same letter at different samples indicates no significant difference $(P>0.05)$.

*Mean \pm SD for 2 sample/treatment.

comparing the area of the hippuric acid peak and the control. Sample with low molecular weight $(\leq 3 \mathrm{kDa})$ has the highest ACE inhibitory activity percentage with value of $80.39 \pm 2.69 \%$ followed by sample with molecular weight between $3-10 \mathrm{kDa}$ with value of $49.40 \pm 2.63 \%$ and sample with molecular weight $\geq 10$ $\mathrm{kDa}$ with value of $42.73 \pm 5.08 \%$. Sample with molecular weight of $3-10 \mathrm{kDa}$ and sample with molecular weight $\geq 10 \mathrm{kDa}$ does not have any significant difference $(P \leq 0.05)$ and this may indicate that peptides with larger molecular weight are present in the 3-10 kDa sample fraction. Similar findings are reported by Ghassem et al. [24] whereby sample with molecular weight less than $3 \mathrm{kDa}$ has the highest ACE inhibitory activity and [27] where sample with molecular weight less than $1 \mathrm{kDa}$ has the highest ACE inhibitory activity. Campos et al. [27] reported that the ACE inhibitory activity is affected by the peptide chain containing less than 6 hydrophobic amino acids and this is supported by Zhang et al. [17] that reported the ACE inhibitory activity is affected by the presence of hydrophobic amino asid at the C- terminal of a tripeptide.

Based on Graph 3 and Graph 1, the result obtained for the ACE inhibitory activity and the peptide content in the sample fraction are inversely proportional. The low molecular weight sample $(\leq 3 \mathrm{kDa})$ has the lowest peptide content but the highest ACE inhibitory activity. Kapel et al. and Tsai et al. [28, 29] also obtained a similar result whereby the high peptide content in a sample does not affect ACE inhibitory activity but sample with molecular weight less than 400 Da gave high ACE inhibitory activity result. Byun and Kim [30] reported that the ultrafiltation process using a $3 \mathrm{kDa}$ membrane does not only separates the molecular weight of peptides in samples, but also concentrates the lower molecular weight sample which helps in the ACE inhibitory activity detection. The result obtained from this research indicates that ACE inhibitory activity is affected by the molecular weight of the polypeptides in the sample and not the peptide content in the sample.

\section{CONCLUSION}

Chicken skin contains peptides that are able to inhibit angiotensin converting enzyme (ACE). ACE inhibitory activity is affected by the molecular weight of polypeptide in the sample. The percentage of ACE inhibitor is highest in sample fraction with weight $\leq$ $3 \mathrm{kDa}$ followed by sample fraction weight $3-10 \mathrm{kDa}$ and sample fraction weight $\geq 10 \mathrm{kDa}$. The peptide content and soluble protein content does not affect the ACE inhibitory activity in this analysis. This is summarized from the result of the peptide content and soluble protein content which is lowest for the sample with molecular weight $\leq 3 \mathrm{kDa}$ and highest for sample with molecular weight $\geq 10 \mathrm{kDa}$. The low value for peptide content and soluble protein content for sample with molecular weight $\leq 3 \mathrm{kDa}$ may be caused by the loss of peptides with a larger molecule size during ultrafiltration. Based on the result of peptide content and ACE inhibitory activity in the samples, it can be concluded that ACE inhibitory activity is not affected by peptide with large molecule size in the sample.

\section{REFERENCES}

[1] Li GH, Le GW, Shi YH, Shrestha S. Angiotensin-I Converting Enzyme Inhibitory Peptidas Derived from Food Proteins and 
Their Physiological and Pharmalogical Effects. Nutri Res 2004; 24: 469-86.

http://dx.doi.org/10.1016/j.nutres.2003.10.014

[2] Norris R, Fitzgerald RJ. Antihypertensive Peptidas from Food Proteins. InTech: Creative Commons Attribution License 2013.

[3] Feddern V, Kupski L, Cipolatti EP, et al. Physico-Chemical Composition, Fractionated Glycerides and Fatty Acid Profile of Chicken Fat. Eur J Lipid Sci Technol 2010; 112: 1277-84. http://dx.doi.org/10.1002/ejlt.201000072

[4] Onuh JO, Aluko RE, Aliani M. Inhibitions of Renin and Angiotensin Converting Enzyme Activities by Enzymatic Chicken Skin Protein Hydrolysate. Food Res Int 2013; 53(1): 260-67.

http://dx.doi.org/10.1016/j.foodres.2013.05.010

[5] Abedin MZ, Riemschneider R. Chicken Skin CollagenMolecular Diversity and Susceptibility to Neutral Proteinases. Pharmaceut Ind 1984; 46: 532-35.

[6] Lasekan A, Fatimah AB, Dzulkifly H. Potential of chicken byproducts as sources of useful biological resources. Waste Management 2013; 33: 552-65. http://dx.doi.org/10.1016/j.wasman.2012.08.001

[7] Gomez-Guillen MC, Gimenez B, Lopez-Caballero ME, Montero MP. Functional and bioactive properties of collagen and gelatin from alternative sources: a review. Food Hydrocolloid 2011; 25: 1813-27. http://dx.doi.org/10.1016/j.foodhyd.2011.02.007

[8] Kim SK. Marine Proteins and Peptides: Biological Activities and Applications. John Wiley \& Sons Ltd. United Kingdom 2013. http://dx.doi.org/10.1002/9781118375082

[9] Scopes RK. Protein Purification: Principles and Practice 3rd Edition. Springer.com. United States of America 1993.

[10] Nielsen PM, Petersen D, Dambmann C. Improved Method For Determining Food Protein Degree Of Hydrolysis. J Food Sci 2001; 66(5): 642-46. http://dx.doi.org/10.1111/j.1365-2621.2001.tb04614.x

[11] Spellman D, McEvoy E, O'Cuinn G, FitzGerald RJ. Proteinase and exopeptidase hydrolysis of whey protein: Comparison of the TNBS, OPA and $\mathrm{pH}$ stat methods for quantification of degree of hydrolysis. Int Dairy J 2003; 13: 447-53. http://dx.doi.org/10.1016/S0958-6946(03)00053-0

[12] Church FC, Swaisgood HE, Porter DH, Catignani GL. Spectrophotometric Assey Using O-Phthaldialdehyde for Determination of Proteolysis in Milk and Isolated Milk Proteins. J Dairy Sci 1983; 66: 1219-27. http://dx.doi.org/10.3168/jds.S0022-0302(83)81926-2

[13] Lowry $\mathrm{OH}$, Rosebrough NJ, Farr AL, Randall RJ. Protein Measurement with the Folin Phenol Reagent. J Biol Chem 1951; 193-65.

[14] Wu J, Ding X. Characterization Of Inhiition And Stability Of Soy-Protein-Derived Angiotensin I-Converting Enzyme Inhibitory Peptidas. Food Res Int 2002; 35: 367-75. http://dx.doi.org/10.1016/S0963-9969(01)00131-4

[15] Nilsang $S$, Lertsiri $S$, Suphantharika M, Assavanig A. Optimization of enzymatic hydrolysis of fish soluble concentrate by commercial proteases. J Food Eng 2005; 70: 571-78.

http://dx.doi.org/10.1016/j.jfoodeng.2004.10.011

[16] Slizyte R, Rustad T, Storro I. Enzymatic hydrolysis of cod (Gadus morhua) by-products: Optimization of yield and properties of lipid and protein fractions. Proc Biochem 2005; 40: $3680-92$.

http://dx.doi.org/10.1016/j.procbio.2005.04.007
[17] Zhang Y, Olsen K, Grossi A, Otte J. Effect of pretreatment on enzymatic hydrolysis of bovine collagen and formation of ace-inhibitory peptides. Food Chem 2013; 141: 2343-54. http://dx.doi.org/10.1016/j.foodchem.2013.05.058

[18] Kritinsson HG, Rasco BA. Fish Protein Hydrolysates: Production, Biochemical and Functional Properties. CRC Crit Rev Food Sci Nutri 2000; 32: 1-39.

[19] Arihara K, Ohata M, Toldra F. Functional Properties of Bioactive Peptidas Derived from Meat Proteins. New York. USA 2006.

[20] Tsai JS, Chen JL, Pan BS. ACE inhibitory peptide3s identified from the muscle protein hydrolysates of hard clam (Meretrix lusoria). Proc Biochem 2008; 43: 743-47. http://dx.doi.org/10.1016/j.procbio.2008.02.019

[21] Hall GM. Methods of Testing Protein Functionality. Blackie Academic And Profesional. Great Britain 1996. http://dx.doi.org/10.1007/978-1-4613-1219-2

[22] Wilson K, Walker JM. Principles and Techniques of Biochemistry and Molecular Biology Seventh Edition. Cambridge University Press. United States of America (USA) 2010.

[23] Balti R, Nedjar-Arroume N, Bougatef A, Guillochon D, Nasri M. Analysis of Novel Angiotensin I-Converting Enzyme Inhibitory Peptidas from Enzymatic Hydrolysates of Cuttlefish (Sepia Officinalis) Muscle Proteins. J Agric Food Chem 2010; 58(6): 3840-46 http://dx.doi.org/10.1021/jf904300a

[24] Ghassem M, Arihara K, Babji AS. Isolation, Purification And Characterisation Of Aangiotensin I-Converting EnzymeInhibitory Peptides Derived From Catfish (Clarias batrachus) Muscle Protein Thermolysin Hydrolysates. Int J Food Sci Technol 2012; 47: 2444-51. http://dx.doi.org/10.1111/j.1365-2621.2012.03122.x

[25] Ko SC, Kang MC, Lee JK, et al. Effect of Angiotensin IConverting Enzyme (Ace) Inhibitory Peptida Purified from Enzymatic Hydrolysates of Styela Plicata. Eur Food Res Technol 2011; 233: 915-22. http://dx.doi.org/10.1007/s00217-011-1585-7

[26] Wang JP, Hu JE, Cui JZ, Bai XF, Du YG, Miyaguchi Y. Purification and Identification of an ACE Inhibitory Peptida from Oyster Proteins Hydrolysate and the Antihypertensive Effect of Hydrolysate in Spontaneously Hypertensive Rats. Food Chem 2008; 111: 302-308. http://dx.doi.org/10.1016/j.foodchem.2008.03.059

[27] Campos MRS, González FP, Guerrero LC, Ancona DB. Angiotensin I-Converting Enzyme Inhibitory Peptides of Chia (Salvia hispanica) Produced by Enzymatic Hydrolysis. Int J Food Sci 2013 http://dx.doi.org/10.1155/2013/158482

[28] Kapel R, Rahhou E, Lecouturier D, Guillochon D, Dhulster P. Characterization of an Antihypertensive Peptida from an Alfafa White Protein Hydrolysate Produced by a Continuous Enzymatic Membran Reactor. Proc Biochem 2006; 41: 196166.

http://dx.doi.org/10.1016/j.procbio.2006.04.019

[29] Tsai JS, Lin TC, Chen JL, Pan BS. The Inhibitory Effects of Freshwater Clam Muscle Protein Hydrolysates on Angiotensin I Converting Enzyme. Proc Biochem 2006; 41: 2276-81.

http://dx.doi.org/10.1016/j.procbio.2006.05.023

[30] Byun H-G, Kim S-K. Purification and Characterization of Angiotensin I Converting Enzyme (Ace) Inhibitory Peptidas from Alaska Pollack (Theragra Chalcogramma) Skin. Proc Biochem 2001; 36: 1155-62. http://dx.doi.org/10.1016/S0032-9592(00)00297-1 